\title{
EFL Teachers' Evaluation and Adaptation of the Reading Lessons in the Piloted Tieng Anh 12
}

\author{
Nguyen Thi My Nga ${ }^{1}$, Do Minh Hung ${ }^{2}$ \\ ${ }^{1}$ Can Tho University, Vietnam \\ ${ }^{2}$ Dong Thap University, Vietnam
}

\begin{abstract}
This descriptive study aims to investigate how EFL teachers evaluate reading lessons in the piloted Tieng Anh 12 and how they make adaptations in their teaching practices. The current study was conducted with the participation of 62 teachers in different high schools in the Mekong Delta, Vietnam. Quantitative and qualitative data were collected via questionnaire and semi-structured interviews. There are some main following findings. First, EFL teachers highly appreciated the reading lessons in the piloted Tieng Anh 12 in relation to goals, topics, authenticity, skills, tasks and vocabulary. Second, the participants revealed there were some weaknesses in reading lessons needed to be considered. Thirdly, EFL teachers shared their adaptations for weaknesses of the reading lessons by using some adaptation techniques such as deleting, modifying, replacing and simplifying.
\end{abstract}

Keywords - evaluation, adaptation, Tieng Anh 12, reading lessons, EFL teachers

\section{INTRODUCTION}

Textbooks are of great value in the processes of teaching and learning (e.g., Cunningsworth, 1995; Haycraft, 1998; O’Neill, 1982; Sheldon, 1988; Tanner, 1988). Cunningsworth (1995) also stated that textbooks are an effective resource for self-directed learning, an effective source for presentational material, a source of ideas and activities, a reference source for students and a syllabus where they reflect pre-determined learning objectives, and support for less experienced teachers who are yet to gain confidence. However, Grant (1987) claimed the perfect book does not exist. It means that every textbook might also has weaknesses although it is published by a trusty publisher. As a result, textbook used in the classroom should go through an evaluation. The consideration is made based on clear answer whether the textbook meets curriculum's objectives, satisfy a particular class or an individual student, match learners' context, and other aspects.

In Vietnam, recognizing the importance of foreign languages in the context of globalization and internationalization, in 2010 Vietnam Educational Publishing House, in collaboration with MacMillan Education and Pearson Education published a new series of English textbooks for Vietnamese schools from grade 3 to grade 12 under MoET decision. These textbooks aim to promote learners' English communicative competence (MoET, 2006). Learners are supposed to become more active, creative, and cooperative participants in communication activities, and to engage in meaningful interaction within a specific context (Hoang et al., 2006). In terms of the piloted textbooks for high school students, they aim to improve high school students' language competence as well as life skills. Specifically, by the end of the upper secondary level, students will have reached Level 3 of the Vietnam National Foreign Language Framework. According to Circular No.01/2014/TT-BGDĐT, Level 3 is equivalent to Level B1 of the Common European Framework of References for Languages (CEFR). Recently, high school students in general and students in grade 12 in particular have encountered many difficulties in mastering communication skills, especially reading comprehension skill. Those students claimed that they had difficulty in doing reading tasks because they could not get the information from the reading texts. Among four English skills, reading is the most challenging ones. Most students who find it difficult to master reading skill feel bored and disappointed with reading periods. There are a variety of reasons for this such as reading topics, the lengths of reading texts, reading activities, students' limited vocabulary or goals of reading lessons. Hence, reading lessons need to be taken into account. Additionally, those piloted textbooks were designed for public use, not for any particular learning environment. Furthermore, to the researcher's best knowledge, little research has been done on evaluating reading lessons in the series of textbooks used for English language teaching and learning in Vietnamese high schools so as to find out whether these reading lessons actually help learners communicate in English. All the above-mentioned reasons facilitate 
DOI: $\underline{10.51386 / 25815946 / \mathrm{ijsms}-\mathrm{v} 4 \mathrm{i} 4 \mathrm{p} 130}$

Volume: 4 Issue: 4

July to August 2021

https://www.ijsmsjournal.org

the researcher's motivation to conduct a study to find out how EFL teachers evaluate reading lessons in the piloted Tieng Anh 12 and how they make adaptations of reading lessons for improvement.

\section{LITERATURE REVIEW}

\subsection{Reading}

Reading can be defined as a process of interaction in which the reader and the text interacted with each other in order to understand the text (Warnick, 1996). Grabe (1991) also stated that reading is more of an interactive process in which the reader makes use of information from his/her background knowledge as well as information from the printed page. In terms of reading comprehension, Mayer (2005) reported reading comprehension is a process of extracting meaningful information from text for the purpose of reading. To understand textual content, readers need to know and use strategies (metacognition) before, during and after reading to correctly understand what is being read. In this study, reading comprehension is defined as a communicatively active process of deriving meanings from a given text-based making use of learners' prior knowledge, reading strategies to understand and response to the reading texts.

\subsection{Textbook evaluation}

Hutchinson and Waters (1987) defined evaluation as "a matter of judging the fitness of something for a particular purpose" (p.96). Worthen and Sanders (1973) considered "evaluation is the determination of the worth of a thing. It includes obtaining information for use in judging the worth of a program, product, procedure, or object, or the potential utility of alternative approaches designed to attain specified objectives" (p.19). In terms of textbook evaluation, it is an attempt to quantify assess the potential worth of textbooks (Tomlinson, 2011). It entails making judgements on the effects of textbooks on the individuals who use them (learners, instructors, and administrators). According to Ur (1996, p.184), a textbook contains a teaching framework and syllabus, ready-made texts and tasks, economy, convenience, guidance and autonomy. Identifying the strengths and weaknesses in textbooks, optimum use can be made of strong points, and weaker points can be adapted or substituted from other books as mentioned in Cunningsworth (1995, p. 14). In this study, textbook evaluation is defined as the process of gathering the information about reading sections in a textbook and analyzing data to determine what works well (its merits) and what requires supplementing, balancing, or deleting (its shortcomings) for a particular class or group of learners.

\section{Why to evaluate textbooks?}

There are many different reasons to evaluate textbooks. To begin with, Grant (1987) believed that "perfect book does not exist" (p.8), hence textbook evaluation is necessary to determine the suitability of textbooks to specific goals (Waters, 1989). Cunningsworth (1995) further explained the evaluators desire to know whether the textbook used closely matches the needs of the learners as well as the objectives, methods, and values of the teaching program. Murphy (1985) remarked that all teachers should learn how to evaluate materials because it is not merely a responsibility of experts, but the development of language teaching is crucial. It is totally true that when instructors participate in textbook evaluation activities, they will have a thorough awareness of the textbook's properties. This helps teachers find appropriate activities in the textbook and lets teachers regulate and modify them to meet learners' needs, teaching and learning contexts. In the present study, the results of textbook evaluation uncover the strengths and weaknesses of reading lessons in the piloted Tieng Anh 12 in general, and their relevance to a specific context in particular. Moreover, the results will contribute greatly to the improvement of the quality of teaching and learning reading in schools implementing the piloted Tieng Anh 12.

\subsection{Material adaptation}

Material adaptation "involves changing existing materials in some form so that they can become suitable for specific purposes, learners, teachers or situation" (Tomlinson \& Masuhara, 2004, p.1). This indicates that while adapting existing material for pedagogical purposes in an EFL setting, teachers must consider learners' context, learning styles, and their attitudes.

\section{Why to make adaptations?}

As mentioned above, textbooks sometimes do not fit learners' needs, learning styles, attitudes, context where learners are studying. Therefore, the teachers have to define what to change, eliminate, add or extend to make the material more suitable for the circumstances in which it is being used (McDonough \& Shaw, 1993). Moreover, if teachers over-use a textbook over a period of time, they will find themselves teaching the same type of activities in the same order repeatedly. Even with good textbooks, students may find English learning to 
DOI: $\underline{10.51386 / 25815946 / \mathrm{ijsms}-\mathrm{v} 4 \mathrm{i} 4 \mathrm{p} 130}$

become regular and hence less and less motivating in such a circumstance (Harmer, 2003, p. 257). Teachers are responsible for getting learners involved by developing or adapting materials to their specific needs, as well as avoiding boring activities. From reasons mentioned above, it is suggested that textbooks be carefully adapted as essential resources for learners and as a useful guide for novice teachers in order to satisfy demands of learners while maintaining teacher professionalism.

\subsection{Description of the piloted Tieng Anh 12}

The selected book for evaluation consists of ten units. The first five units are taught in the first semester and the rest in the second one. Each unit which focuses on a single theme consists of eight parts such as Getting Started, Language (Vocabulary, Pronunciation, and Grammar), Reading, Speaking, Listening, Writing, Communication \& Culture, and Looking Back \& Project. Moreover, there are four Reviews that provide opportunities for learners to check their learnt knowledge after three units.

In term of reading lessons in the piloted Tieng Anh 12, there are four or five activities in each reading lesson from more controlled to free types. The first activity is a pre-reading stage that presents the particular topic of a reading text, giving learners the chance to generate ideas related to the topic or invoke their current knowledge. It also allows learners to participate in reading lessons. The next two or three activities are the stage of whilereading. Scanning, skimming can be essential skills that are applied in different types of tasks, such as matching the headings with the paragraphs, True/ False or Not Given, multiple choice, answering questions, vocabulary in a text. The last action of each reading lesson is the post-reading task. Typically, it is a discussion that allows learners to express their own views or thoughts or their own experiences with their partners about the issues mentioned in a reading passage. As a result, readers can access the text in depth and practice the words shown in the text successfully.

\subsection{Theoretical framework for reading lesson evaluation and adaptation}

\subsubsection{Framework for reading lesson evaluation}

The evaluation framework which was used in the current study was a combination of the guidelines in Circular No.31/2015/TT-BGDDT, Vietnam and the theories of many authors.

\section{Circular No. 31/2015/TT-BGDDT for reading}

There are three criteria for Reading skill

Criterion 31: The system of reading lessons is diversified with attractive themes and develops different reading comprehension skills of learners.

Criterion 32: Reading activities are diversified to provide learners with opportunities for practice of other language skills upon each reading lesson.

Criterion 33: Length and difficulty of reading lessons are suitable to learner's level.

\section{Framework for reading lesson evaluation}

Framework for reading lesson evaluation which was adapted and modified the checklists of six authors consisting of Cunningsworth, 1995; Doud \& Celce-Murcia, 1979; Litz, 2005; Guariento \& Morley, 2001; Ur, 1996. There are six criteria for reading lesson evaluation consisting of goals/ objectives, topics, skills, authenticity, vocabulary and tasks/ activities.

\subsubsection{Framework for reading lesson adaptation}

If the course book is not appropriate for a particular group of learners, the teachers have some adaptation techniques to consider. The criteria for adaptation tailored from the adaptation techniques of McGrath Ian (2002), Tomlinson (2003), Harmer (2007) consist of deleting, modifying, re-ordering, replacing and simplifying the activities in reading lessons in the piloted Tieng Anh 12.

\subsection{Research design}

\section{III.METHODOLOGY}

The current study was designed as a descriptive one that makes use of a mix-method approach in order to investigate EFL teachers' evaluation and adaptation of reading lessons in the piloted Tieng Anh 12. In this case, both quantitative and qualitative methods were employed for data collection and data analysis. 
DOI: $\underline{10.51386 / 25815946 / \mathrm{ijsms}-\mathrm{v} 4 \mathrm{i} 4 \mathrm{p} 130}$

\subsection{Research participants}

Participants being EFL high school teachers working at high schools in the Mekong Delta, Vietnam and using the piloted Tieng Anh 12 were invited to take part in this research on the basic of convenient sampling technique. Those teachers teaching the piloted Tieng Anh 12 at high schools must have $\mathrm{C} 1$ certificates based on CEFR framework. All teacher participants have different demographic information. The 62 participants were requested to complete the questionnaires at first. Then, seven respondents were invited to attend semi-structured interviews.

\subsection{Research instruments}

In order to answer the two research questions, the questionnaire and the semi-structured interview were utilized as research instruments.

The questionnaire was composed with three main sections. Its details are as follows.

Section 1: The first section aims at collecting teachers' gender, age, phone number or email, professional qualification, years of teaching experience and years of using the piloted Tieng Anh 12 and workplace.

Section 2: The second one was designed to collect data on the teachers' perceptions, evaluation and adaptation of reading lessons in the piloted Tieng Anh 12. This section was adapted and combined chunks of the information from theories mentioned in the literature review, the guidelines in Circular No.31/2015/TT-BGDDT for reading and the checklists of the authors (Please see section 2.5.1.2). There are 6 clusters including Goals, Topics, Authenticity, Skills, Vocabulary and Tasks/ Activities with 52 closed-ended items. The items were designed in the statements requiring participants to express their ideas, evaluation and feelings on a five-point Likert scale ranging from Strongly Disagree to Strongly Agree. At the end of every question cluster, there is an "other comments" item added to gain participants' own opinions.

Section 3: The last section is about teachers' adaptation of reading lessons in the piloted Tieng Anh 12 based on adaptation technique theories and the piloted Tieng Anh 12. There are 2 small parts. In the first part, the participants were asked to answer items ranging in 5-frequency scale from "No" to "Very much" to mark the amount of adaptation the teachers make in each reading lesson. In the second part, the teachers answer items designed with 5-point Likert scales with choices from "Never" to "Always" to choose which frequency of a particular adaptation techniques they used in their teaching practices. Correspondingly, the researcher investigated which adaptation techniques were used most and least frequently or even never. Moreover, an "other comments" item was added to figure out more adaptation techniques that can be mentioned by the respondents.

There were three main questions in the interview on teachers' further perspectives of reading lessons in the piloted Tieng Anh 12 as well as their adaptation in their teaching practices. Specifically, the first main question was related to strengths of reading lessons in the piloted Tieng Anh 12. The next question focused on weaknesses of reading lessons in the piloted Tieng Anh 12. The last question was about how teachers adapt to make reading lessons better. Moreover, this question aimed at to get more specific adaptation which the respondents made in each reading lesson. In the interview, if the interviewees have difficulty in answering the questions or provides only a brief response, the interviewer can use cues or prompts to encourage the interviewee to consider the question further.

\section{IV.FINDINGS}

\subsection{Questionnaire results}

To collect data on evaluation of the reading lessons in the piloted Tieng Anh 12, a questionnaire with 52 items was used. The collecting data gained from the questionnaires were transferred to SPSS version 20 for quantitative data analysis. First, the Scale Test was run to check the reliability of the questionnaire. The results of the scale test showed that the reliability coefficient of the questionnaire satisfied the statistical reliability $(\alpha=$ $0.923)$.

The participants responded to the questionnaire by checking five-Likert scales of individual items ranging from Strongly Disagree to Strongly Agree in Section 2 and five frequency scales from No to Very much to mark the amount of adaptation the teachers make in each reading lesson and 5-point Likert scales with choices from Never to Always to choose which frequency of a particular adaptation techniques they used in their teaching practices in Section 3. 
DOI: $\underline{10.51386 / 25815946 / \mathrm{ijsms}-\mathrm{v} 4 \mathrm{i} 4 \mathrm{p} 130}$

\subsubsection{The teachers' evaluation of the reading lessons in the piloted Tieng Anh 12}

A Descriptive Statistics Test was run to examine the overall evaluation of the reading lessons in the piloted Tieng Anh 12 by the participants. The results of the test were presented in Table I below.

\section{Table I:}

Teachers' evaluation of the reading lessons $(\mathrm{N}=62)$

\begin{tabular}{lllll}
\hline Variable & Min. & Max. & Mean & SD \\
\hline Goals & 2.56 & 4.56 & 3.8333 & .39361 \\
\hline Topics & 2.20 & 4.50 & 3.8371 & .38464 \\
\hline Authenticity & 2.86 & 5.00 & 3.8433 & .39629 \\
\hline Skills & 2.00 & 4.46 & 3.7965 & .48891 \\
\hline Vocabulary & 2.00 & 5.00 & 3.8134 & .53112 \\
\hline Tasks & 2.00 & 5.00 & 3.8065 & .60372 \\
\hline Overall Evaluation & 2.94 & 4.58 & 3.8204 & .33631 \\
\hline
\end{tabular}

From Table I, it can be seen that the total mean score of teachers' evaluation of the reading lessons in the piloted Tieng Anh 12 is fairly high $(\mathrm{M}=3.82)$. It could be inferred that the teachers highly evaluated the reading lessons in the piloted Tieng Anh 12.

A One Sample T-Test was conducted to evaluate whether participants' evaluation $(\mathrm{M}=3.82)$ is at the high level or at the very high level $(M=4.5)$. The result indicated that the difference between participants' evaluation and the test value $(4.5)$ was significantly different $(t=-15.91, p=.000)$. The results supported the conclusion the teacher highly evaluated the reading lessons in the piloted Tieng Anh 12. Besides, teachers' evaluation of those aspects of the reading lessons in the piloted Tieng Anh 12 were the same which were at high level. Among six aspects, the mean score of Authenticity was the highest $(\mathrm{M}=3.843)$, followed by Topics $(\mathrm{M}=3.837)$, Goals ( $\mathrm{M}$ =3.833), Vocabulary $(M=3.813)$, Skills $(M=3.796)$, and Activities $(M=3.806)$.

Next, the One-way ANOVA and Independent Sample T-Tests were conducted to check whether the teachers with different demographic information have any differences in their evaluation. Table II below showed the results of these tests.

Table II:

Differences in overall evaluation of the teachers having different demographic information $(\mathrm{N}=62)$

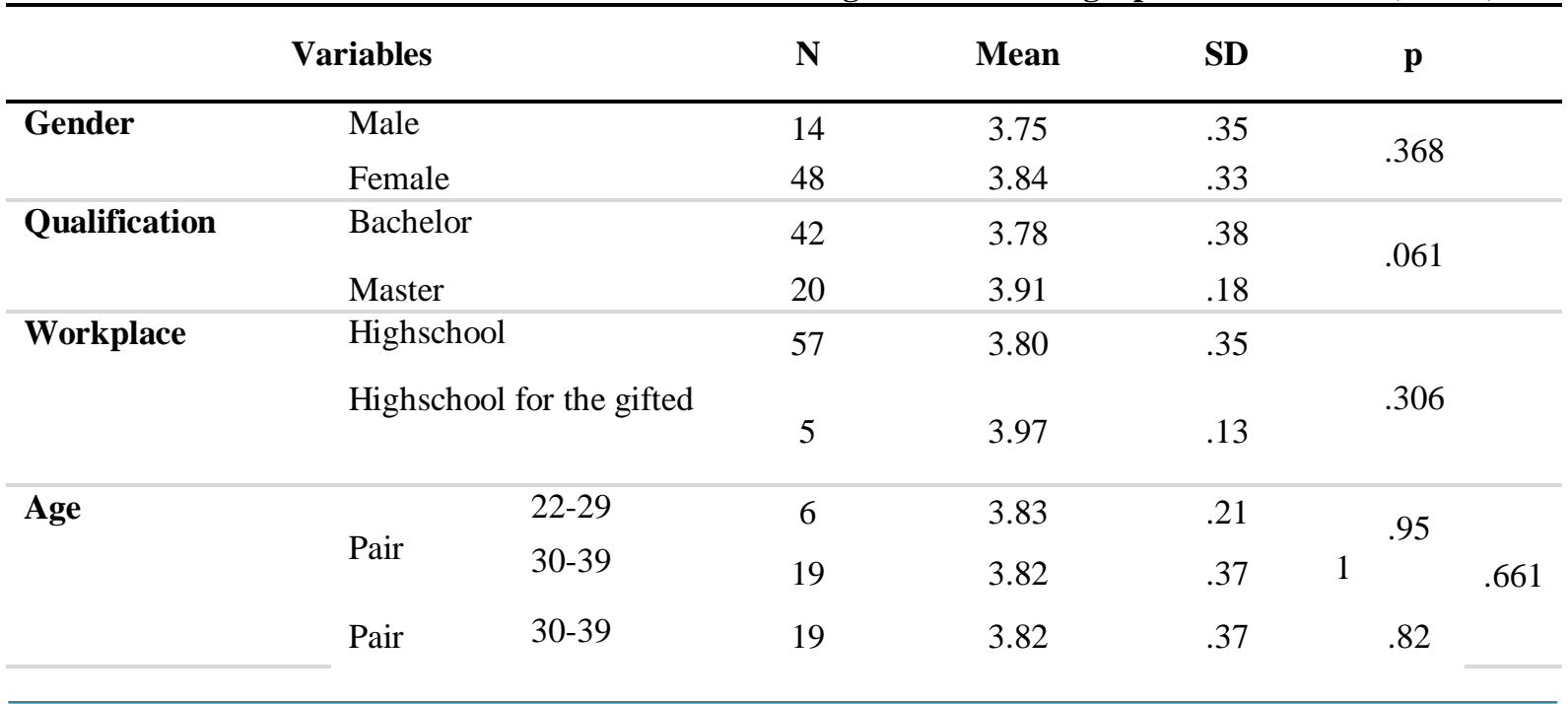


DOI: $\underline{10.51386 / 25815946 / \mathrm{ijsms}-\mathrm{v} 4 \mathrm{i} 4 \mathrm{p} 130}$

\begin{tabular}{|c|c|c|c|c|c|c|c|c|}
\hline & & $40-49$ & 32 & 3.79 & .35 & 1 & & \\
\hline & \multirow{2}{*}{ Pair } & $40-49$ & 32 & 3.79 & .35 & \multirow{2}{*}{\multicolumn{2}{|c|}{.20}} & \\
\hline & & $>50$ & 5 & 4.00 & .24 & & & \\
\hline & \multirow{2}{*}{ Pair } & $>50$ & 5 & 4.00 & .24 & \multirow{2}{*}{\multicolumn{2}{|c|}{.23}} & \\
\hline & & $22-29$ & 6 & 3.83 & .21 & & & \\
\hline \multirow{10}{*}{$\begin{array}{l}\text { Teaching } \\
\text { Experience }\end{array}$} & \multirow[b]{2}{*}{ Pair } & $2-5$ & 3 & 3.80 & .31 & \multirow{2}{*}{\multicolumn{2}{|c|}{.96}} & \multirow{10}{*}{.898} \\
\hline & & $6-10$ & 16 & 3.81 & .37 & & & \\
\hline & \multirow[b]{2}{*}{ Pair } & $6-10$ & 16 & 3.81 & .37 & \multirow{2}{*}{\multicolumn{2}{|c|}{.55}} & \\
\hline & & $11-15$ & 10 & 3.89 & .25 & & & \\
\hline & \multirow[b]{2}{*}{ Pair } & $11-15$ & 10 & 3.89 & .25 & \multirow{2}{*}{\multicolumn{2}{|c|}{.31}} & \\
\hline & & $16-20$ & 17 & 3.76 & .34 & & & \\
\hline & \multirow[b]{2}{*}{ Pair } & $16-20$ & 17 & 3.76 & .34 & \multirow{2}{*}{\multicolumn{2}{|c|}{.47 }} & \\
\hline & & $>20$ & 16 & 3.85 & .38 & & & \\
\hline & \multirow{2}{*}{ Pair } & $>20$ & 16 & 3.85 & .38 & \multirow{2}{*}{\multicolumn{2}{|c|}{.82}} & \\
\hline & & $2-5$ & 3 & 3.80 & .31 & & & \\
\hline \multirow{10}{*}{$\begin{array}{l}\text { Years of teaching/ } \\
\text { using the textbook }\end{array}$} & \multirow[b]{2}{*}{ Pair } & $<1$ & 4 & 3.54 & .46 & \multirow{2}{*}{\multicolumn{2}{|c|}{.07}} & \multirow{10}{*}{.046 } \\
\hline & & $1-2$ & 19 & 3.85 & .26 & & & \\
\hline & \multirow[b]{2}{*}{ Pair } & $1-2$ & 19 & 3.85 & .26 & \multirow{2}{*}{\multicolumn{2}{|c|}{.74}} & \\
\hline & & $3-4$ & 23 & 3.88 & .38 & & & \\
\hline & \multirow[b]{2}{*}{ Pair } & $3-4$ & 23 & 3.88 & .38 & \multirow{2}{*}{\multicolumn{2}{|c|}{.73}} & \\
\hline & & $5-6$ & 9 & 3.93 & .17 & & & \\
\hline & \multirow[b]{2}{*}{ Pair } & $5-6$ & 9 & 3.93 & .17 & \multirow{2}{*}{\multicolumn{2}{|c|}{.00}} & \\
\hline & & $>6$ & 7 & 3.544 & .32 & & & \\
\hline & \multirow{2}{*}{ Pair } & $>6$ & 7 & 3.544 & .32 & \multirow{2}{*}{\multicolumn{2}{|c|}{.99}} & \\
\hline & & $<1$ & 4 & 3.543 & .46 & & & \\
\hline
\end{tabular}

As observed in Table II, the results of Independent Sample T-tests showed that there was no significant difference in teachers' overall evaluation of the reading lessons in the piloted Tieng Anh 12 based on their genders, qualifications and workplaces (the p-value are $.368, .061$ and .306 respectively). Besides, the results of One-Way ANOVA tests showed that there was no difference among pairs of teachers with different ages $(\mathrm{p}=.951 ; .821 ; .209$ and .239). The same went for teacher with different teaching experience $(\mathrm{p}=.965 ; .556 ; .311 ; .473$ and .829$)$.

However, for Years of teaching/ using the textbook, there was difference in evaluation among teachers with different years of teaching or using the textbook $(\mathrm{p}=.046)$. Specifically, the mean score of the teachers with 5 to 6 years of teaching or using the piloted Tieng Anh 12 was the highest $(M=3.93)$. It supported the conclusion that teachers with different years of teaching the textbook had different evaluation of the reading lessons in the piloted Tieng Anh 12. 
DOI: $\underline{10.51386 / 25815946 / \mathrm{ijsms}-\mathrm{v} 4 \mathrm{i} 4 \mathrm{p} 130}$

Volume: 4 Issue: 4

July to August 2021

https://www.ijsmsjournal.org

\subsubsection{The teachers' adaptation of the reading lessons in the piloted Tieng Anh 12}

For this section, teachers were asked to rate the level of frequency of adaptation of the reading lessons in the piloted Tieng Anh 12 on the five-point Likert scale from "No" to "Very much" and from "Never" to "Always".

First, A Descriptive Statistics Test was run to examine the amount of adaptation made by the participants. The results of the test were presented in Table III.

Table III:

Teachers' adaptation of the reading lessons $(\mathrm{N}=62)$

\begin{tabular}{lcccc}
\hline Variable & Min. & Max. & Mean & SD \\
\hline The amount of adaptation & 1.43 & 2.86 & 2.2 & .34 \\
\hline
\end{tabular}

As can be seen in Table III, the mean score of the amount of teachers' adaptation was low (M=2.2). One Sample T-Test was conducted to evaluate whether the mean score was significantly different from 2.5 , the mean score for moderate adaptation. The result showed that the mean score of the amount of teachers' adaptation was significantly different from $2.5(\mathrm{t}=-7.3, \mathrm{p}=.000)$. The finding indicated that the amount of teachers' adaptation was just at low degree.

Next, the result of teachers' frequency of using adaptation techniques, measured by a Descriptive Statistics Test, was displayed in Table IV.

Table IV:

Teachers' frequency of using adaptation techniques in the piloted Tieng Anh $12(\mathrm{~N}=62)$

\begin{tabular}{lllll}
\hline Variable & Min. & Max. & Mean & SD \\
\hline Frequency level of using adaptation techniques & 2.00 & 4.67 & 2.97 & .46 \\
\hline
\end{tabular}

From Table IV, it can be seen, the mean score of frequency level is medium. $(M=2.97)$. A One Sample T-Test was conducted to check whether teachers' frequency of using adaptation techniques $(M=2.97)$ is at the medium level or at the high level $(\mathrm{M}=3.5)$. The result indicated that the difference between teachers' frequency of using adaptation techniques and the test value (3.5) was significantly different $(t=-9.0, p=.000)$. Teachers' frequency of using adaptation techniques is just at the moderate level.

As mentioned in Chapter 3, there are 5 adaptation techniques. A Frequency Descriptive Test was run to find out teachers' frequency level of using adaptation techniques, reported in Table V below.

\section{Table V:}

Teachers' frequency level of using each adaptation technique $(\mathrm{N}=62)$

\begin{tabular}{|c|c|c|c|c|c|c|c|}
\hline \multirow{2}{*}{ Items } & \multirow{2}{*}{ Mean } & \multicolumn{2}{|c|}{$\begin{array}{l}\text { Never and } \\
\text { Seldom }\end{array}$} & \multicolumn{2}{|c|}{ Sometimes } & \multicolumn{2}{|c|}{ Often and Always } \\
\hline & & $\mathrm{F}$ & $\mathrm{P}(\%)$ & $\mathrm{F}$ & $\mathrm{P}(\%)$ & $\mathrm{F}$ & $\mathrm{P}(\%)$ \\
\hline $\begin{array}{l}\text { I delete an activity or some } \\
\text { activities of reading lessons } \\
\text { in the piloted Tieng Anh } 12 \\
\text { which are inappropriate to } \\
\text { aims of reading lessons. }\end{array}$ & 2.74 & 20 & 32.2 & 36 & 58.1 & 6 & 9.7 \\
\hline $\begin{array}{l}\text { I modify an activity or some } \\
\text { activities to provide more } \\
\text { opportunities for more }\end{array}$ & 3.23 & 8 & 12.9 & 34 & 54.8 & 20 & 32.2 \\
\hline
\end{tabular}


DOI: $\underline{10.51386 / 25815946 / \mathrm{ijsms}-\mathrm{v} 4 \mathrm{i} 4 \mathrm{p} 130}$

different reading purposes.

I re-order an activity or some activities of reading lessons in the piloted Tieng 3.00 $12 \quad 19.4$ 41

66.1 9 14.5 Anh 12.

I replace an activity or some activities of reading lessons in the piloted Tieng Anh 12.

$19 \quad 30.6$

35

56.5

8

12.9

I simplify an activity or some activities in reading lessons in the piloted Tieng 3.06 $10 \quad 16.1$

$16.1 \quad 40$

64.5 12 Anh 12.

As shown in Table $\mathrm{V}$, among those adaptation techniques, the mean score of modifying technique was the highest $(M=3.23)$. Besides, the mean score of deleting technique was the lowest $(M=2.74)$. Moreover, the results from a Frequency Descriptive Test supporting the results mentioned above showed that among those techniques, the most frequently used adaptation technique by teachers was modifying (32.2\%). The least frequently used technique was deleting $(9.7 \%)$. The results of other techniques were simplifying $(\mathrm{M}=3.06)$, reordering $(\mathrm{M}=3.00)$ and replacing $(\mathrm{M}=2.84)$.

\subsection{Interview results}

The semi-structured interviews were conducted aiming to gain insight into teachers' evaluation and adaptation of reading lessons in the piloted Tieng Anh 12. In other words, some questions were asked to probe the participants' viewpoints about reading lessons in the piloted Tieng Anh 12, relating to the strengths and weaknesses of reading lessons and how the participants made adaptations.

\subsubsection{Strengths of reading lessons in the piloted Tieng Anh 12}

The respondents talked about strengths of reading lessons in the piloted Tieng Anh 12 in terms of goals, topics, authenticity, skills, vocabulary, and activities.

With respect to Skills, all seven respondents agreed that in reading lessons, students have many chances to practice reading strategies including skimming, scanning, reading for details, summarizing, referencing, completing the information. They said, respectively

\section{Students have the opportunity to practice reading skills...}

(Teacher B)

Besides, other teachers added more evaluation of skills. They said that in reading lessons, students also have opportunities to practice speaking, listening and writing skills; to learn life-skills from the contents of reading texts. Moreover, working in teams is also trained as follows

...learn much things about life-skills, the world of their future job...

\section{(Teacher A)}

they have just listening skills.

...in the post-reading section there is often an activity that helps students consolidate what learned in the reading section and also practice speaking, writing and

\section{(Teacher B)}

members.

In addition, students can train teamwork skills; discuss and exchange ideas with group

\section{(Teacher F)}

Regarding Activities, all of the participants reported that activities in reading lessons are diverse and graded that are suitable for all students' levels. They stated 
DOI: $\underline{10.51386 / 25815946 / \mathrm{ijsms}-\mathrm{v} 4 \mathrm{i} 4 \mathrm{p} 130}$

Volume: 4 Issue: 4

July to August 2021

https://www.ijsmsjournal.org

Tasks are diverse and graded that are suitable for all students. Students from weak to very good English ability can do tasks in reading lessons.

(Teacher D)

In terms of Authenticity, most of the interviewees agree that reading lessons in the piloted are authentic as follows

knowledge.

I think this reading section provides students with authentic and up-to-date sources of

(Teacher C)

About Vocabulary, the responses of all seven interviewees are similar. All of them emphasized that the amount of vocabulary of each reading unit are good. Vocabulary is diverse and not too difficult for students to understand and guess the meaning of new words. Furthermore, some new words in reading lessons have been mentioned in semester exams or even high school graduation exams. The respondents expressed

confidence to take

The amount of vocabulary which can meet students' need for reading can boost students' exams, especially high school graduation exam.

(Teacher A)

...vocabulary provided in each unit of reading is good and rich. It is categorized into topics which students can easily guess the meaning from the context. Moreover, some of those words sometimes appear in tests or exams which students can easily recognize, remember and are confident to do the tests or exams.

\section{(Teacher C)}

With respect to Topics, the common views among the interviewees were that there are a variety of reading topics. Some topics are updated and some are also familiar to students that helps students get involved to lessons easily. For example, teacher $\mathrm{G}$ presented

Reading topics are interesting, rich and updated.

(Teacher G)

In addition, teacher $\mathrm{F}$ also gave a pretty review about topics.

and.... I find some

Diverse reading topics, which provide students with a lot of knowledge, good information future job. My students are very successful.

interested and active, and the reading class is also very

\section{(Teacher F)}

Moreover, the results from the open-ended question in the questionnaire was positive. Three participants also agreed that there are diverse and interesting reading topics.

In terms of Goals, there is no difference in the participants' responses. They stated that the goals of reading lessons are clear, as follows

Goals are clear. On the first page of the book there are goals for each skill in each unit. They are very clear and understandable.

\section{(Teacher A)}

However, one of the interviewees stated that aims of reading lessons do not match the general goals of the curriculum. She said that

But compared with the overall goal of the curriculum, it should be re-examined. The overall goal of the piloted Tieng Anh 12 is developing students' communicative competence, but I don't think it works well. Students have not yet improved their reading skills through activities in reading lessons. 
DOI: $\underline{10.51386 / 25815946 / \mathrm{ijsms}-\mathrm{v} 4 \mathrm{i} 4 \mathrm{p} 130}$

(Teacher B)

\subsubsection{Weaknesses and adaptation of reading lessons in the piloted Tieng Anh 12}

Seven interviewees were asked the question about weaknesses of reading lessons in the piloted Tieng Anh 12 and how they adapt reading lessons. The participants had different perceptions about weaknesses and different ways to make adaptation.

The first weakness of reading lessons in the piloted Tieng Anh 12 most the participants mentioned was that many new words in reading lessons are academic and difficult for their students do guess or understand the meanings.

...In addition, new words mentioned in reading lessons are also very difficult that the students cannot understand the meaning of the passage as well as answer the exercise questions.

(Teacher C)

.... some words are academic...

(Teacher D)

Teacher C suggested the solution for this aspect. She presented

...I often teach my students a lot of vocabulary in pre-reading stage so that they can read and understand the reading text better.

\section{(Teacher C)}

Moreover, most of the interviewees expressed their dissatisfaction with Tasks on vocabulary. In most reading lessons, there is a task on vocabulary. There is a list of five to six descriptions, definitions or synonyms. The requirement of the task is to find the words in the reading texts which have the given meaning. The tasks are so boring and difficult for students. The teachers reported adaptations, as follows

I will adapt this exercise. There are two columns, a column including definitions or synonyms, one including new words in reading texts. Ask students to read the text, guess the meaning and match the new word with the given meaning column. For example, there are Unit 1, task 3; unit 2 task 3; unit 6 task 4; unit 8, task 2; unit 9, task 3 and unit 10, task 3.

(Teacher B)

Besides, most teachers laid emphasis on a weak point of Reading tasks in the piloted Tieng Anh 12 and provided adaptations. Reading tasks mainly focus on short answer questions. They expressed

...but I saw a lot of tasks in reading lessons only focus on answering questions, which do not meet the needs of the students' graduation exam.

\section{(Teacher B)}

I adapted unit 3, task 3; unit 1, task 4; unit 5, task 2; unit 9, task 4....Tasks on answering questions were replaced with multiple choice questions...I redesigned about 5 multiple choice questions for details, not true, referring and guessing the meaning from the context.

(Teacher C)

Teacher D added more adaptation for some specific reading tasks.

I adapted some tasks. Task 4 of Unit 1 is simplified. I just ask my students to answer about two or three random questions. The rest is homework. Because there are many tasks and many questions in tasks that can not be practiced in fifty-five minutes. Task 4 of Unit 3 was deleted because it was difficult for students. Like Task 4 of Unit 1, Task 3 of Unit 5 is also simplified. Task 2 of Unit 7 is replaced with multiple choice task and modified one more reading gap fill summary.

(Teacher D)

Regarding Topics, teacher A, B, and C expressed their dissatisfaction with reading topics. 
DOI: $\underline{10.51386 / 25815946 / \mathrm{ijsms}-\mathrm{v} 4 \mathrm{i} 4 \mathrm{p} 130}$

Volume: 4 Issue: 4

July to August 2021

https://www.ijsmsjournal.org

Reading topics are not interesting.

(Teacher B)

There are some topics that are difficult and unfamiliar to my students.

(Teacher C)

\section{Discussion}

This section discusses the results of the study in relation to relevant studies in order to answer the research questions about EFL teachers' evaluation and adaptation of reading lessons in the piloted Tieng Anh 12.

\subsection{EFL teachers' evaluation of reading lessons in the piloted Tieng Anh 12}

The results from the questionnaire shows that EFL teachers highly evaluated reading lessons in the piloted Tieng Anh 12. It could be indicated that reading lessons in the piloted Tieng Anh 12 are fairly good.

In terms of goals, the results from questionnaire indicated that after grade 12, students could entirely achieve the goals for reading lessons in the piloted Tieng Anh 12. However, the results from the interviews, most of the teachers just mentioned that goals are clear, which is not enough information to gain insight into the issues. There is the only interviewee who is confident to state that if teachers just follow reading lessons in the piloted Tieng Anh 12, after grade 12 many students can not achieve the goals for reading lessons in the piloted Tieng Anh 12. This is due to new words in reading lessons, reading tasks in the piloted Tieng Anh 12 and students' language proficiency. The finding is different from the study by Cunningsworth (1995) that neither do reading lessons suit students' levels nor match the goals of the curriculum. These maybe bring troubles to students as well as teachers; hence, some adjustments should be considered and some adaptation should be made to fit in specific teaching and learning contexts.

In terms of topics, the results showed that EFL teachers' evaluation on the topics of the reading lessons in the piloted Tieng Anh 12 is at high level. It can be seen that reading lessons involve familiar topics such as life stories, the mass media, the world of work, choosing a career. The contents of reading texts are rather familiar and relevant to real-life and appropriate with the learners' background knowledge. The interviewees also appreciated the variety of the topics. It was consistent with the finding of the study by Ur (1996), who indicated that topics should be interesting and varied in order to satisfy a wide range of learner levels, learning styles, and interests. However, the results from the interviews revealed that there are also some topics which are unfamiliar and difficult for $12^{\text {th }}$ graders such as urbanisation, artificial intelligence, the green movement. Noticeably, the results from the interview revealed that although the topics are various, the students may find it hard to listen or talk about all of these topics. The respondents suggested that to the unfamiliar and difficult topics, teachers should give more help with sub-tasks, vocabulary so that students could have opportunities to build their background knowledge. It was different from the findings of Foster and Skehan (1996, 1999); Skehan and Foster $(1997,2001)$ which indicated that if the topic is familiar to learners, they tend to be fluent with greater accuracy.

Regarding skills, the results of the current study reported that the participants were relatively satisfied with numerous reading strategies involved in different reading activities which were compatible with students' levels. Besides, students also have opportunities to practice their listening, writing and speaking skills through activities in the post-reading stage. However, some interviewees complained that reading lessons offers students activities mainly focusing on predicting or finding details skills which do not meet students' professional needs consisting of language skills and competencies needed in the future. It was different from a study by Grabe and Stoller (2013) that students should be conscious of reading strategies in order to become strategic readers. Therefore, in order to help students improve their reading skill, EFL teachers should consider, redesign, take advantages as well as effectively use the available inputs.

In terms of authenticity of reading lessons in the piloted Tieng Anh 12, EFL teachers' evaluation on this aspect is also at high level. The results indicate that some reading topics and the contents of the reading texts involved in reading lessons in the piloted Tieng Anh 12 are related to real-life which make students interested in getting involved in the lessons. In other words, the information in reading texts is authentic because the students could not only make direct connection between the learning inputs and their prior knowledge but also expand their awareness and enrich their experience. The findings are quite consistent with the finding of a study by Mishan (2005), who presented for language learners, authentic texts are the best sources of rich and varied 
DOI: $\underline{10.51386 / 25815946 / \mathrm{ijsms}-\mathrm{v} 4 \mathrm{i} 4 \mathrm{p} 130}$

Volume: 4 Issue: 4

July to August 2021

https://www.ijsmsjournal.org

comprehensible input, which has an impact on affective learning factors such as motivation, empathy, and emotional involvement.

With respect to vocabulary, EFL teachers have a good satisfaction with vocabulary in reading lessons in the piloted Tieng Anh 12 which is diverse and themed. However, the results from the interview reported that some new words in reading lessons are academic and difficult for students to guess their meanings as well as understand them. Moreover, vocabulary activities are so and boring because they are almost stereotyped which repeated for each unit. Besides, vocabulary activities whose objective is helping students guess vocabulary's meaning from the reading contexts are considered to be difficult for students, especially weak language ability students. They are different from the findings of the study by Cunningsworth (1995), who confirmed that students should be exposed to vocabulary items in various contexts so they can memorize, use fluently and fully understand the vocabulary system.

Regarding reading tasks, the results show that there a diverse reading tasks in the piloted Tieng Anh 12 which do provide opportunities for learners to practice language skills are balanced individual response, pair works and group works. Also, the tasks create both teacher-student and student-student interaction. It was in line with the finding of study by Hutchinson (1988) who stated that to be considered good classroom tasks, they should include opportunities for learners to interact with their peers. In addition, the attempt to create opportunities for learners to work in pairs and in groups is consistent to the challenges in maximizing classroom interaction found out by Lucha and Berhanu (2015) and Suryati (2015). However, the results from the interview indicated that some teachers are not satisfied with some reading activities in the while reading stages stereotyped in each unit which are so boring. They added those reading activities which mainly focus on the answering question task can not help students improve their reading skills effectively, so the teachers redesigned and modified some different reading activities to provide students more chances to practice most of reading strategies as well as to satisfy students' professional needs.

\subsection{EFL teachers' adaptation of reading tasks in the piloted Tieng Anh 12}

The results from the questionnaire shows that EFL teachers' adaptation on reading lessons in the piloted Tieng Anh 12 is at low level. It could be indicated that the teachers do not make many adaptations to reading lessons in the piloted Tieng Anh 12.

Concerning adaptation, the specific tasks in reading lessons were adapted based on the drawbacks of reading lessons found out in the interview.

Firstly, to most of the teachers, many new words in reading lessons are academic and difficult. Therefore, they often teach students a lot of vocabulary in pre-reading stage or replace difficult words with synonyms or paraphrase so that students can read and understand the reading text better.

Besides, tasks on vocabulary which are boring because they are repeated for each reading lessons are difficult to students' levels. The adaptation was changing tasks. This was in line with the strategies of adaptation of McGrath Ian (2002) and ways of material adaptation of Tomlinson (2003) and Harmer (2007) that teachers can adapt materials by using several options such as omission, reduction, replacement, etc. In the same vein, task 3 of Unit 1; task 3 of unit 2; task 4 of unit 6; task 2 of unit 8; task 3 of unit 9 and task 3 of unit 10 were replaced with other tasks.

Additionally, reading tasks which are boring do not work well with their roles- improving students' reading skill. For example, there are task 4 of unit 1, task 4 of unit 2, task 3 of unit 3, task 3 of unit 5 , task 2 of unit 7, task 4 of unit 9 and task 4 of unit 10. The adaptations made for the tasks were replacement.

Last but not least, to some tasks that are too difficult to students' level are adapted by modifying the content, simplifying, deleting such as task 4 of unit 1, task 4 of unit 3 task 3 of unit 5 , task 2 of unit 7.

\section{VI.IMPLICATIONS AND CONCLUSION}

In light of the major findings from the current study, some implications will be presented as follows with the purpose of improving the quality of reading lessons in the piloted Tieng Anh 12 and EFL teachers' practices in adapting reading lessons in teaching and learning process.

Firstly, it has been found that some reading topics in the piloted Tieng Anh 12 are neither interesting nor familiar to students (e.g., unit 2, unit 7, unit 8). Therefore, English textbook writers should pay more attention to 
DOI: $\underline{10.51386 / 25815946 / \mathrm{ijsms}-\mathrm{v} 4 \mathrm{i} 4 \mathrm{p} 130}$

Volume: 4 Issue: 4

July to August 2021

https://www.ijsmsjournal.org

topics when designing reading lessons so that the topics can meet students' interest. In addition, tasks on vocabulary should also be considered because they are not effective in helping students in guessing the meanings of new words from reading contexts (e.g., unit 1, task 3; unit 2 task 3 ; unit 6 task 4; unit 8, task 2; unit 9 , task 3 and unit 10, task 3). Moreover, from the study, it could be suggested that tasks on practicing reading skill provided in reading lessons should be sufficient and appropriate because many of them mainly focus on short answer questions (e.g., unit 1, task 4 ; unit 3 , task 3 ; unit 5 , task 3 ; unit 7 , task 2 ; unit 9 , task 4 ; unit 10 , task 4)

Next, the Ministry of Education and Training should organize more meetings, conferences to raise teachers' awareness of textbook evaluation as well as textbook adaptation. Moreover, it also a great chance for EFL teachers to present their challenges when teaching the piloted Tieng Anh 12, especially reading lessons in the piloted Tieng Anh 12 as well as share their teaching experience.

Thirdly, EFL high school teachers should be constantly developing their learning and teaching abilities. Moreover, EFL high school teachers should be active in evaluating and adapting textbooks because no textbook is perfect for a particular class or an individual student. EFL high school teachers should adapt textbooks so that they become more suitable for teaching contexts and learners. Furthermore, EFL teachers who used the textbooks had better share their evaluation of the textbooks and effective adaptations which might be useful references for novice teachers.

In conclusion, the study on EFL teachers' evaluation and adaptation of reading lessons in the piloted Tieng Anh 12 has reached its purposes. EFL teachers highly appreciated reading lessons in the piloted Tieng Anh 12 in clear goals, diverse and updated topics, contents related to real-life, good study skills, quite good activities and varied and sufficient vocabulary. However, the teachers also revealed that there are some restrictions of reading lessons in the piloted Tieng Anh 12 as follows

Some reading topics are hard and unfamiliar to students with make students get difficulties in understanding reading texts.

Tasks on vocabulary are difficult.

Tasks for practicing reading skills are stereotyped and are not enough to practice reading strategies, reading skills.

Some new words in reading lessons are academic and difficult.

For those weaknesses of reading lessons in the piloted Tieng Anh 12, the teachers made some adaptations, which is also the answer to the second question. The adaptations made for those weaknesses were deleting, modifying, replacing and simplifying the activities in reading lessons in the piloted Tieng Anh 12 to be appropriate to students' levels and interests.

\section{ABOUT THE AUTHORS}

Nguyen Thi My Nga is a teacher of English at a high school in Can Tho, Vietnam. She completed a bachelor's degree of English in Education in 2012. She is currently an MA student at Can Tho University. Her research interests include reading skills and strategies, and teaching methodology. She is also keen on improving the learning experience and applying innovative approaches for EFL students.

Dr. Do Minh Hung has been teaching English at Dong Thap University, Vietnam, for more than 20 years. He holds a doctoral degree in Applied Linguistics and has published several journal articles in the areas of English instruction and English-Vietnamese translation.

\section{REFERENCES}

[1] Cunningsworth, A. (1995). Choosing your coursebook. Oxford: Heinemann.

[2] Daoud, A.M. \& Celce-Murcia, M. (1979). Selecting and evaluating a textbook. In M. Celce-Murcia and L. McIntosh (Eds.), Teaching English as a second or foreign language (pp. 302- 307). Cambridge, MA: Newbury House Publishers. 
DOI: $\underline{10.51386 / 25815946 / \mathrm{ijsms}-\mathrm{v} 4 \mathrm{i} 4 \mathrm{p} 130}$

Volume: 4 Issue: 4

July to August 2021

https://www.ijsmsjournal.org

[3] Foster, P., \& Skehan, P. (1996). The influence of planning on performance in task-based learning. Studies in Second Language Acquisition, 18(3), 299-324.

[4] Foster, P., \& Skehan, P. (1999). The influence of source of planning and focus of planning on task-based performance. Language Teaching Research, 3(3), 215-247.

[5] Grabe, W. (1991) Current Developments in Second Language Reading Research. TESOL Quarterly, 25(3), $375-406$.

[6] Grabe, W., \& Stoller, F.L. (2013). Teaching reading for academic purposes. In Teaching English as a second or foreign language, ed. M. Celce-Murcia, D. M. Brinton, and M. A. Snow. 4th ed. Boston: Heinle Cengage.

[7] Grant, N. (1987). Making the most of your textbook. London: Longman.

[8] Guariento, W., \& Morley, J. (2001). Text and task authenticity in the EFL classroom. ELT Journal, 55(4), 347-353.

[9] Harmer, J. (2003). The practice of English language teaching. New York: Longman.

[10] Harmer, J. (2007). The practice of English language teaching ( $4^{\text {th }}$ ed.). Harlow, England: Pearson Education.

[11] Haycraft, J. (1998). An Introduction to English Language Teaching. London: Longman.

[12] Hoang, V.V., Nguyen, T.C., Hoang, X.H. (2006). Innovating ELT Methodology in Vietnam's Upper secondary school. Hanoi: Education Publisher.

[13] Hutchinson, T. \& Waters, A. (1987). English for Specific Purposes: A Learning-centered Approach. Cambridge: Cambridge University Press.

[14] Litz, D.R.A. (2005). Textbook evaluation and ELT management: A South Korean Case Study. Asian EFL Journal, 48(1), 1-53.

[15] Mayer, R. (2005). The cognitive theory of multimedia learning. In Richard E. Mayer (Ed.), The Cambridge Handbook of Multimedia Learning, 31-48. Cambridge: Cambridge University Press. http://dx.doi.org/10.1017/CBO9780511816819.004

[16] McDonough, J. \& Shaw, C. (1993). Materials and Methods in ELT, Oxford: Blackwell.

[17] McGrath, I. (2002). Materials Evaluation and Design for language Teaching. Edinburgh: Edinburgh University Press.

[18] Ministry of Education and Training (2015). Bộ tiêu chí đánh giá sách giáo khoa tiếng Anh giáo dục phổ thông. Issued in accordance with Circular No.31/2015/TT/BGDĐT dated December 14, 2015. Ministry of Education and Training.

[19] Mishan, F. (2005). Designing authenticity into language learning materials. Bristol: Intellect Books.

[20] Murphy, D.F. (1985). Evaluation in language teaching: Assessment, accountability and awareness. In J. C. Alderson (Ed.), Evaluation. (pp.1-17). Oxford: Pergamon.

[21] O’Neill, R. (1982). Why use textbooks?. ELT Journal, 36(2). Oxford University Press.

[22] Sheldon, L. (1988). Evaluating ELT Textbooks and materials. ELT Journal,42(4), 237-246.

[23] Skehan, P., \& Foster, P. (1997). Task type and task processing conditions as influences on foreign language performance. Language Teaching Research, 1(3), 185-211.

[24] Skehan, P., \& Foster, P. (2001). Cognition and tasks. In P. Robinson (Ed.), Cognition and second language instruction (pp.183-205). Cambridge: Cambridge University Press.

[25] Tanner, D. (1988). The textbook controversies, In L. N. Tanner (Ed.). Critical issues on curriculum (pp.122-147). Chicago, IL: National Society for the Study of Education.

[26] Tomlinson, B. (2011). Material Development in Language Teaching (2nd Ed.). Cambridge: Cambridge University Press.

[27] Tomlinson, B. (2003). Developing Materials for Language Teaching. London: Continuum.

[28] Tomlinson, B. \& Masuhara, H. (2004). Developing language course material. Singapore: RELC Portfolio Series.

[29] Ur, P. (1996). A Course in Language Teaching: Practice and Theory. Cambridge: Cambridge University Press.

[30] Worthen, B.R., \& Sanders, J.R. (1973). Educational evaluation: Theory and practice. Worthington, Ohio: Charles A. Jones. 